\title{
Polyphasic Characterization of A Potential Novel Cellulolytic Bacterium Brevibacillus Brevis Strain St-2
}

\author{
P. Prasad ${ }^{1}$, Tanuja $^{2}$, S. Bedi ${ }^{3}$ \\ ${ }^{1}$ Woman Scientist, WOS-A, DST, Govt. of India \\ dr.pinky.prasad@gmail.com \\ ${ }^{2}$ Head, Department of Botany, B.M.D. College, Dayalpur, B.R.A.Bihar University \\ tanujasinghpatna@yahoo.com \\ ${ }^{3}$ Head, Department of Botany, Patna Womens College, Patna, Patna University \\ sheilabedi.pwc@gmail.com
}

\begin{abstract}
The tremendous commercial potential of cellulases in a variety of applications remains the driving force for research in this area. The present study was aimed at isolation and screening of promising cellulolytic strains from locally collected soil samples. A promising cellulose degrading bacterial strain designated as St-2 was isolated from agricultural field. Optimization of fermentation media ingredients and environmental factors were done for optimizing growth of the strain which facilitates effective cellulase production. St-2 showed luxuriant growth on sucrose, lactose, mannitol and inositol whereas the growth was moderate on dextrose and fructose. The strain was able to grow in a wide range of $\mathrm{pH}(5-11)$ and temperature $(4-45 \mathrm{C}$ ) and was tolerant to up to $6 \%(\mathrm{w} / \mathrm{v})$ of $\mathrm{NaCl}$ concentration in the medium. The results indicate wide spectrum adaptability of the strain to variable $\mathrm{pH}$, temperatures and saline concentrations that makes it an advantageous organism to survive in the fluctuating environmental conditions. The optimum $\mathrm{pH}$ and temperature for enzyme production were 7 (with $2.11 \mathrm{U} / \mathrm{ml}$ CMCase activities and $2.22 \mathrm{U} / \mathrm{ml}$ FPase activities) and $37^{\circ} \mathrm{C}$ (with $1.73 \mathrm{U} / \mathrm{ml}$ CMCase activities and $1.92 \mathrm{U} / \mathrm{ml}$ FPase activities), respectively. The morphological and biochemical characteristics of the strain were consistent with those of the genus Brevibacillus. Analysis of the 16S rRNA gene sequence of strain St-2 showed a similarity score of $99 \%$ with Brevibacillus brevis (GenBank Accession No. AB271756) having BLAST score ranging between 821 to 827 bits. Brevibacillus brevis Strain St-2 has been deposited in the GenBank database with the Accession No. KF306223.
\end{abstract}

\section{Indexing Terms/Keywords}

Brevibacillus brevis; cellulolytic; enzyme activities; PCR amplification; phylogenetic analysis.

\section{Academic Discipline And Sub-Disciplines}

Life Sciences.

\section{Subject Classification}

Microbiology.

\section{Type (Method/Approach)}

Quasi-Experimental.

\section{Council for Innovative Research}

\author{
Peer Review Research Publishing System
}

\section{Journal: JOURNAL OF ADVANCES IN BIOTECHNOLOGY}

Vol. 4, No. 1.

www.cirjbt.org ,jbteditor@gmail.com 


\section{INTRODUCTION}

Cellulases constitute one of the most important groups of industrial enzymes capable of bioconversion of renewable lignocellulosic biomass to ethanol as an alternative to liquid fuels. Complete hydrolysis of cellulose to glucose needs synergistic activity of three different enzymes of the cellulase systems: endoglucanase (1,4- $\beta$-glucanglucanohydrolase, EC 3.2.1.4), exoglucanase (1,4- $\beta$-glucancellobiohydrolase, $E C$ 3.2.1.91) and $\beta$-glucosidase ( $\beta$-Dglucosideglucohydolase or cellobiase, EC 3.2.1.21) [1]. The technology for the conversion of cellulosic biomass to sugars is still not very cost-effective, and the cost of the cellulose degrading enzymes and infrastructural set up is very high. A promising strategy to overcome this impediment involves the production of cellulolytic enzymes, hydrolysis of biomass, and fermentation of resulting sugars to desired products in a single process step via a cellulolytic microorganism or consortium. Such "consolidated bioprocessing" (CBP) offers very large cost reductions if there are selected microorganisms that possess the required combination of efficient substrate utilization and product formation capacity [2]. Exploitation of plant biomass as a renewable resource has traditionally been concentrated on the fungi, but lignocellulose-degrading prokaryotes are beginning to receive more attention. Bacteria present an attractive potential for the exploitation of cellulasess and hemicellulasess due to their rapid growth rate, enzyme complexity and extreme habitat variability [3].

In this perspective, the present study was undertaken to explore the microbial world to enumerate cellulose degrading bacteria by survey and collection of the soil samples from agricultural, domestic and municipal wastes.

\section{MATERIALS AND METHODS}

\subsection{Isolation and Selection of Cellulases Producing Bacterial Strains}

Bacterial strains were isolated from soil samples collected locally from Patna region of India, by the standard serial dilution technique on $\mathrm{CMC}$ agar (carboxymethylcellulose, $0.5 \mathrm{~g} ; \mathrm{NaNO}_{3}, 0.1 \mathrm{~g} ; \mathrm{K}_{2} \mathrm{HPO}_{4}, 0.1 \mathrm{~g} ; \mathrm{MgSO}_{4}, 0.05 \mathrm{~g}$; Yeast extract, $0.05 \mathrm{~g}$; Agar, $15 \mathrm{~g} ; \mathrm{H}_{2} \mathrm{O}, 1000 \mathrm{ml}, \mathrm{pH} \mathrm{7.2)} \mathrm{[4]} \mathrm{plates} \mathrm{at} 37^{\circ} \mathrm{C}$ and an incubation period of $48 \mathrm{~h}$ and were purified by repeated sub culturing [5]. The isolates were grown on CMC agar plates for 7 days at $37 \mathrm{C}$ to express cellulose hydrolysis through cellulases production into the medium. The plates were stained with $0.1 \%$ Congo red $(\mathrm{pH} 7.0)$ and counterstained with $1.0 \mathrm{~N} \mathrm{HCl}$ for 15 min that resulted in the production of clear zones of cellulose hydrolysis in the CMC Agar plates around the colonies of the isolates. The bacterial strain having the largest clear zone was selected for its characterization, estimation of cellulase production and identification.

\subsection{Morphological and Cultural Characteristics of the Selected Strains}

Macroscopic morphology of the culture colonies were recorded on the basis of characteristics of colonies on the Nutrient Agar (HiMedia). Microscopic morphology was recorded by observing the aseptically prepared Gram's stained slides of the strain under compound microscope provided with camera (Carl Zeiss). The cultural characteristics of the strain regarding the growth, color and texture of the colony were studied by growing the isolate on different media that included Nutrient Agar, Starch Casein Agar (Soluble starch, $10 \mathrm{~g}$; Casein, $0.3 \mathrm{~g} ; \mathrm{K}_{2} \mathrm{HPO}_{4}, 2 \mathrm{~g} ; \mathrm{CaCO}_{3}, 0.02 \mathrm{~g} ; \mathrm{FeSO}_{4} 7 \mathrm{H}_{2} \mathrm{O}, 0.01 \mathrm{~g}$; $\mathrm{KNO}_{3}, 2 \mathrm{~g} ; \mathrm{MgSO}_{4} 7 \mathrm{H}_{2} \mathrm{O}, 0.05 \mathrm{~g}$; NaCl, $2 \mathrm{~g}$; Agar, $18 \mathrm{~g}$; Distilled $\mathrm{H}_{2} 0,1000 \mathrm{ml}$, pH 7.2), Cellulose Congo Red Agar with slight modification $\left(\mathrm{K}_{2} \mathrm{HPO}_{4}, 0.50 \mathrm{~g}\right.$; $\mathrm{MgSO}_{4}, 0.25 \mathrm{~g}$; cellulose powder, $1.88 \mathrm{~g}$; Congo red, $0.20 \mathrm{~g} ;$ Agar, $15 \mathrm{~g}$;, Gelatine, 2 g; Distilled $\mathrm{H}_{2} \mathrm{O}, 1000 \mathrm{ml}$, pH 7), Stanier's basal medium $\left(\left(\mathrm{NH}_{4}\right)_{2} \mathrm{SO}_{4}, 1 \mathrm{~g} ; \mathrm{K}_{2} \mathrm{HPO}_{4}, 1 \mathrm{~g} ; \mathrm{MgSO}_{4}, 0.2 \mathrm{~g} ; \mathrm{CaCl}_{2}, 0.1 \mathrm{~g} ; \mathrm{FeCl}_{3}\right.$, $0.02 \mathrm{~g}$; Distilled $\left.\mathrm{H}_{2} \mathrm{O}, 1000 \mathrm{ml}, \mathrm{pH} 7.5\right)$, Mcbeth medium $\left(\mathrm{K}_{2} \mathrm{HPO}_{4}, 1 \mathrm{~g} ; \mathrm{CaCO}_{3}, 2 \mathrm{~g} ; \mathrm{Na}_{2} \mathrm{SO}_{4}, 2 \mathrm{~g} ; \mathrm{MgSO}_{4} .7 \mathrm{H}_{2} \mathrm{O}, 1 \mathrm{~g}\right.$; $\left(\mathrm{NH}_{4}\right)_{2} \mathrm{SO}_{4}, 2 \mathrm{~g}$; CMC, $1.0 \%$; Agar, $15 \mathrm{~g}$; Distilled $\mathrm{H}_{2}$ 0, $1000 \mathrm{ml}, \mathrm{pH}$ 7.2) and Casein Starch Peptone Yeast Malt Extract (CSPY-ME) medium $\left(\mathrm{K}_{2} \mathrm{HPO}_{4}, 0.5 \mathrm{~g}\right.$; Casein, $3 \mathrm{~g}$; Maize starch, $10 \mathrm{~g}$; Peptone, $1 \mathrm{~g}$; Yeast extracts, $1 \mathrm{~g}$; Malt extracts, 10 g; Agar, $15 \mathrm{~g}$; Distilled $\left.\mathrm{H}_{2} \mathrm{O}, 1000 \mathrm{ml}, \mathrm{pH} 7.5\right)$. The observations were recorded after 7 days of incubation at $37^{\circ} \mathrm{C}$.

\subsection{Biochemical Characteristics}

$24 \mathrm{~h}$ old cultures of the isolate were used for different biochemical tests that included Indole, methyl red, VogesProskauer, citrate utilization tests, hydrolysis of starch, gelatin, production of catalase, urease, caseinase, hydrogen sulphide and fermentation of sugar [5].

\subsection{Physiological characteristics}

Cellulases activity depends on a complex relationship involving a variety of factors like $\mathrm{pH}$, temperature, incubation period, cations, carbon, and nitrogen sources [6]. Physiological criteria in the present study included the ability of the isolate to utilize different carbons as described by Pridham and Gottlieb [7] using plates containing basal mineral medium $\left(\left(\mathrm{NH}_{4}\right)_{2} \mathrm{SO}_{4}, 2.64 \mathrm{~g} ; \mathrm{KH}_{2} \mathrm{PO}_{4}, 2.38 \mathrm{~g} ; \mathrm{K}_{2} \mathrm{HPO}_{4}, 5.65 \mathrm{~g} ; \mathrm{MgSO}_{4} 7 \mathrm{H}_{2} \mathrm{O}, 1 \mathrm{~g}\right.$; standard saline solution $(0.85 \% \mathrm{w} / \mathrm{v} \mathrm{NaCl}$ in $\mathrm{H}_{2} \mathrm{O}$ ), $1 \mathrm{ml}$; agar, $15 \mathrm{~g} ; \mathrm{H}_{2} \mathrm{O}, 1000 \mathrm{ml}, \mathrm{pH}$ 7.2) supplemented separately with $1 \%$ of dextrose, sucrose, lactose, fructose, mannitol and inositol. The optimization of $\mathrm{pH}$ and temperature for the growth was done by growing the strain on NA plates with variable $\mathrm{pH}$ values $3,5,7,9$ and 11 and incubation temperatures (C) 4, 15, 26, 37, 45, 50,55 and 60 . The growth of the strain at 8 different concentrations of $\mathrm{NaCl}(1-8 \% \mathrm{w} / \mathrm{v})$ in the medium was studied according to the method of Tresner et al. [8].

\subsection{Enzyme Assay}

The selected strain was inoculated in $\mathrm{CMC}$ broth with different $\mathrm{pH}(5,7,9$ and 11) and incubated for 6 days at different temperatures $\left(26,37\right.$ and $\left.45^{\circ} \mathrm{C}\right)$ to determine optimum conditions for enzyme production. The culture broth was 
centrifuged at $10,000 \times \mathrm{g}$ for $10 \mathrm{~min}$ and the supernatant was used as crude cellulase enzyme. The Carboxymethlcellulase activity (CMCase) and filter paper activity (FPase) of the cellulase enzyme was assayed according to the IUPAC instructions [9]. For CMCase activity, $0.5 \mathrm{ml}$ of crude enzyme was added to $0.5 \mathrm{ml}$ of $1 \% \mathrm{CMC}$ in $0.05 \mathrm{M}$ citrate buffer in a test tube and incubated at $50^{\circ} \mathrm{C}$ for $30 \mathrm{~min}$. For FPase activity, $0.5 \mathrm{ml}$ of crude enzyme was added to $1 \mathrm{ml} 0.05 \mathrm{M}$ citrate buffer in a test tube along with a $1 \times 6 \mathrm{~cm}$ filter paper strip and incubated at $50^{\circ} \mathrm{C}$ for $60 \mathrm{~min}$. After incubation, reaction was stopped by the addition of $1 \mathrm{ml}$ of DNS reagent and boiled at $100^{\circ} \mathrm{C}$ in water bath for $5 \mathrm{~min}$. After cooling, sugars liberated were determined by measuring absorbance at $540 \mathrm{~nm}$ using a spectrophotometer (ThermoScientific) and the cellulase production was estimated by using glucose calibration curve. One unit (U) of enzyme activity is expressed as the quantity of enzyme, which is required to release $1 \mu \mathrm{mol}$ of glucose per minute under standard assay conditions.

\subsection{Molecular Characterization and Phylogenetic Analysis of the Isolate}

\subsubsection{Extraction of the Genomic DNA}

The isolate was cultured in Nutrient broth and incubated at $37^{\circ} \mathrm{C}$ for $48 \mathrm{~h}$ in an orbital shaker at $120 \mathrm{rpm}$. Genomic DNA was extracted using DNA Isolation Kit (Qiagen) according to the manufacturer instructions. Electrophoresis was performed in an electrophoresis apparatus (BioRad) using Agarose gel (HiMedia) in $0.8 \%$ (w/v) TBE-EDTA buffer at pH 7. The gel was stained with ethidium bromide and visualized under UV light illumination.

\subsubsection{PCR Amplification}

The PCR amplification reactions were performed using a PCR kit (Sino-American Biotechnology Co., Beijing) in a total volume of $25 \mu \mathrm{l}$. The PCR reaction mixture contained the following solutions: $1 \mu \mathrm{l} 80 \mathrm{ng}$ chromosomal DNA, $0.5 \mu \mathrm{l} 200$ $\mu \mathrm{M}$ of each deoxynucleoside triphosphate (New England Biolabs), $0.8 \mu \mathrm{l} 80$ ng Universal primer 27f (5'AGAGTTTGATCMTGGCTCAG-3'), $0.8 \mu \mathrm{l} 80$ ng Universal primer 1492r (5'-TACGGYTACCTTGTTACGACTT-3'): Escherichia coli 16S rDNA numbering system [10]. $0.5 \mu \mathrm{l} 2.5$ Units Taq Polymerase enzyme, $2.5 \mu$ l $1 \mathrm{X}$ Standard Taq buffer and $18.9 \mu \mathrm{l}$ autoclaved water to make the final volume of $25 \mu \mathrm{l}$. The thermal cycler (Eppendorf mastercycler gradient) was programmed as follows: initial denaturation at $95^{\circ} \mathrm{C}$ for 5 min followed by 30 cycles of denaturation at $95^{\circ} \mathrm{C}$ for $1 \mathrm{~min}$, annealing at $55^{\circ} \mathrm{C}$ for $1 \mathrm{~min}$ and primer extension at $75^{\circ} \mathrm{C}$ for $2 \mathrm{~min}$. At the end of the cycles, the mixture was kept at $75^{\circ} \mathrm{C}$ for $10 \mathrm{~min}$ for a final extension. Approximately $1.5 \mathrm{~kb}$ amplified $16 \mathrm{~S}$ rRNA gene fragment was separated by agarose gel electrophoresis, extracted using Qiaquick gel extraction kit (Qiagen) and purified.

\subsubsection{Partial 16Sr RNA Sequencing}

The partial 16S rRNA sequencing was carried out by the dideoxy chain terminator method using a Big Dye Terminator kit as per the manufacturer's protocol, followed by capillary electrophoresis on an ABI 310 Genetic Analyzer (Applied Biosystem). Four primers used for sequencing were 27f (5'-AGAGTTTGATCMTGGCTCAG-3'), 341f (5'CTGGGAGGCAGCAGTGGG- 3'), 786f (5'- GATTAGATACCCTGGTAG- 3'), 536r (5'- GTATTACCGCGGCTGCTG - 3') and 1492r (5'-TACGGYTACCTTGTTACGACTT-3').

\subsubsection{Sequence Alignment and Phylogenetic Analysis}

The almost complete 16S rRNA gene sequences of strain St-2 $(1,429)$ were aligned manually with the available nucleotide sequences retrieved from the NCBI database using BLASTN [11]. The evolutionary tree was inferred using the Neighbor Joining method [12] using the software MEGA 5.05 [13].

\section{RESULTS}

\subsection{Isolation and Selection of Cellulases Producing Bacterial Strains}

In the course of isolation, 42 cellulolytic bacterial strains were isolated from soil samples collected locally from Patna region of India, by the standard serial dilution technique on CMC agar plates at $37^{\circ} \mathrm{C}$ and an incubation period of $48 \mathrm{~h}$. Among the isolates, the strain designated as St-2 was selected for the present study. The selection was based on extent of production of clear zones on CMC Agar around the colonies when tested with Congo red dye. The strain St-2 was maintained on Nutrient Agar slants at $4 \mathrm{C}$ for further investigation.

\subsection{Morphological and Cultural Characteristics}

The colonies of the isolate were white with smooth margins on the Nutrient Agar medium. The micro-morphological observation revealed gram positive rods. The cultural characteristics of the isolate are presented in Table 1 . The strain showed luxuriant growth on all the specified media. Typically, the colonies were white to grey in color. 
Table 1. Culture characteristics of Brevibacillus brevis strainSt-2 on different media

\begin{tabular}{|cccc|}
\hline Medium & Growth & Color & Texture \\
\hline Nutrient Agar & +++ & White & Powdery \\
Starch Casein Agar & +++ & Grey & Powdery \\
Cellulose Congo Red Agar & +++ & Grey & Powdery \\
CSPYME & +++ & Dirty white & Slimy \\
Mcbeth medium & +++ & Dirty white & Dry \\
Stanier's basal medium & +++ & Dirty white & Dry \\
\hline
\end{tabular}

+ poor; ++ moderate; +++ luxuriant

\subsection{Biochemical Characteristics}

The biochemical characterization of the isolate was done by the standard methods as described by Dubey and Maheshwari [5]. The strain gave positive results for the catalase, citrate utilization, fermentation of sucrose, hydrogen sulphide production and Voges- Proskauer tests; and was amylase negative, caseinase negative, gelatinase negative, indole negative, methyl red negative and urease negative.

\subsection{Physiological Characteristics}

The data regarding the physiological characteristics of the strain are presented in the Table 2. The strain showed luxuriant to moderate growth on all the specified carbohydrates used in the present study. The $\mathrm{pH}$ and temperature of an organism's environment has the maximum influence on its growth. The temperature also plays an important role in the hydrolysis of cellulose as it affects the rate of hydrolysis as well as the stability of the cellulases enzyme [14]. The present investigation revealed that the strain was able to grow luxuriantly at all the specified $\mathrm{pH}$ except $\mathrm{pH} 3$ and at temperatures ranging from $4 \mathrm{C}$ up to $45^{\circ} \mathrm{C}$ restricting the growth beyond that. The strain was slightly halophilic as it could grow in the medium with up to $6 \% \mathrm{w} / \mathrm{v}$ saline concentration, with optimum growth at $1 \% \mathrm{NaCl}$.

Table 2. Physiological characteristics of Brevibacillus brevis strainSt-2

\begin{tabular}{|cc|cc|}
\hline Carbon utilization & Growth & Range of pH & Growth \\
\hline Dextrose & ++ & 3 & Nil \\
Sucrose & +++ & 5 & +++ \\
Lactose & +++ & 7 & ++ \\
Fructose & ++ & 9 & +++ \\
Mannitol & +++ & 11 & Growth \\
\hline Range of temperature & Growth & NaCl tolerance & +++ \\
\hline $4^{\circ} \mathrm{C}$ & + & $1 \%$ & ++ \\
$15^{\circ} \mathrm{C}$ & ++ & $2 \%$ & ++ \\
$26^{\circ} \mathrm{C}$ & +++ & $3 \%$ & ++ \\
$37^{\circ} \mathrm{C}$ & +++ & $4 \%$ & ++ \\
$45^{\circ} \mathrm{C}$ & ++ & $5 \%$ & ++ \\
$50^{\circ} \mathrm{C}$ & - & $6 \%$ & - \\
$55^{\circ} \mathrm{C}$ & - & $7 \%$ & - \\
$60^{\circ} \mathrm{C}$ & - & $8 \%$ & + \\
\hline & No growth; & + poor growth; & ++ moderate growth; +++ luxuriant growth
\end{tabular}

\subsection{Enzyme Assay}

The effect of environmental factors such as temperature and $\mathrm{pH}$ are found to be important parameters that influence enzyme activities and production. The enzyme hydrolyzes substrate in the $\mathrm{pH}$ range of 4.0 to 9.0 , with maximum activity occurring at pH 7.0 [6]. Maximum CMCase activity was found at pH 7.5 in Aspergillus niger (Z10 wild type strain) as reported by GoKhan et al. [15] and at 6-7 in A. niger [16]. Similar findings are reported by Garcia-Martinez et al. [17] and Prasetson and Doelle [18] for maximum enzyme production by Clostridium thermocellum and Cellulomonas. Our findings 
are in accordance with that of theirs. In the present study, the CMCase activity by the isolate at varying pH level showed that the activity was increased from pH $5(2.04 \mathrm{U} / \mathrm{ml})$ to $7(2.11 \mathrm{U} / \mathrm{ml})$. Further increase in pH level to 9 and 11 resulted in considerable decrease in enzyme activity $(1.92 \mathrm{U} / \mathrm{ml}$ and $1.70 \mathrm{U} / \mathrm{ml}$, respectively). Similar trend was observed for FPase activity where it was estimated $2.14 \mathrm{U} / \mathrm{ml}$ at $\mathrm{pH} 5,2.22 \mathrm{U} / \mathrm{ml}$ at $7,2.15 \mathrm{U} / \mathrm{ml}$ at 9 and $2.11 \mathrm{U} / \mathrm{ml}$ at 11 , respectively as shown in Figure 1.

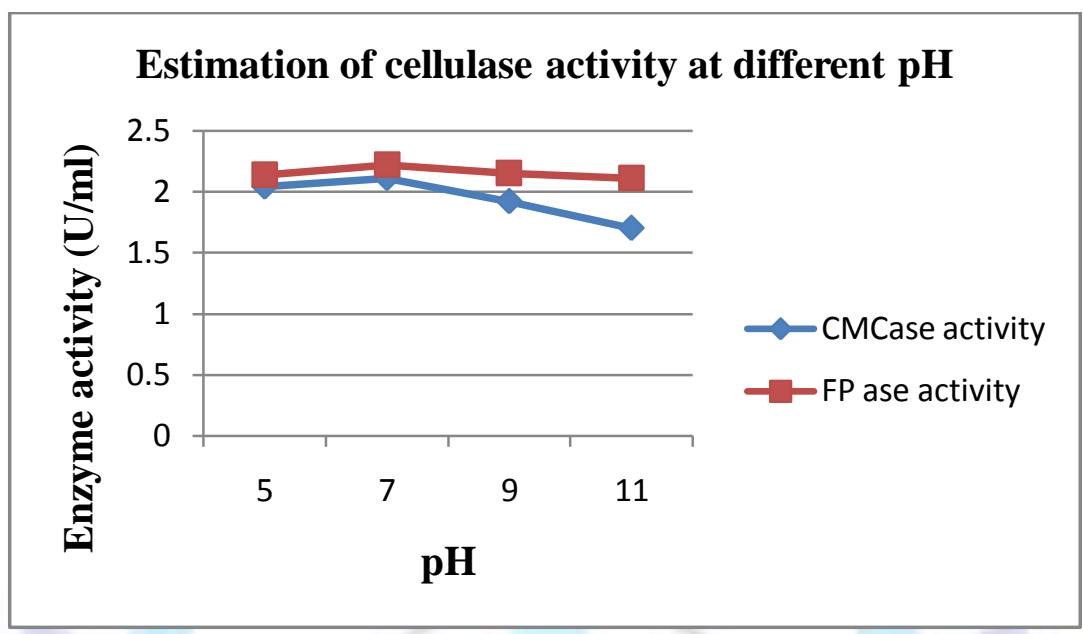

Fig1: Estimation of CMCase and FPase activity $(\mathrm{U} / \mathrm{ml})$ of Brevibacillus brevis strain St-2 at different pH

In general, the optimum temperature required for enzyme production by bacterial strains differs from fungal strains. Cellulase activities from Trichoderma sp. and other mesophilic cellulolytic fungi are at their optimum when assayed at about $50{ }^{\circ} \mathrm{C}$ [19] whereas for the bacterial strains it is found to be $40{ }^{\circ} \mathrm{C}$ [6]. In the present study, the enzyme activity was more at $37{ }^{\circ} \mathrm{C}, 1.73 \mathrm{U} / \mathrm{ml} \mathrm{CMCase}$ activities and $1.92 \mathrm{U} / \mathrm{ml}$ FPase activities, whereas it was less at $26{ }^{\circ} \mathrm{C}(1.07 \mathrm{U} / \mathrm{ml}$ CMCase activities and $1.18 \mathrm{U} / \mathrm{ml}$ FPase activities) and $45{ }^{\circ} \mathrm{C}(0.96 \mathrm{U} / \mathrm{ml}$ CMCase activities and $1.15 \mathrm{U} / \mathrm{ml} \mathrm{FPase}$ activities). The data are presented in Figure 2.

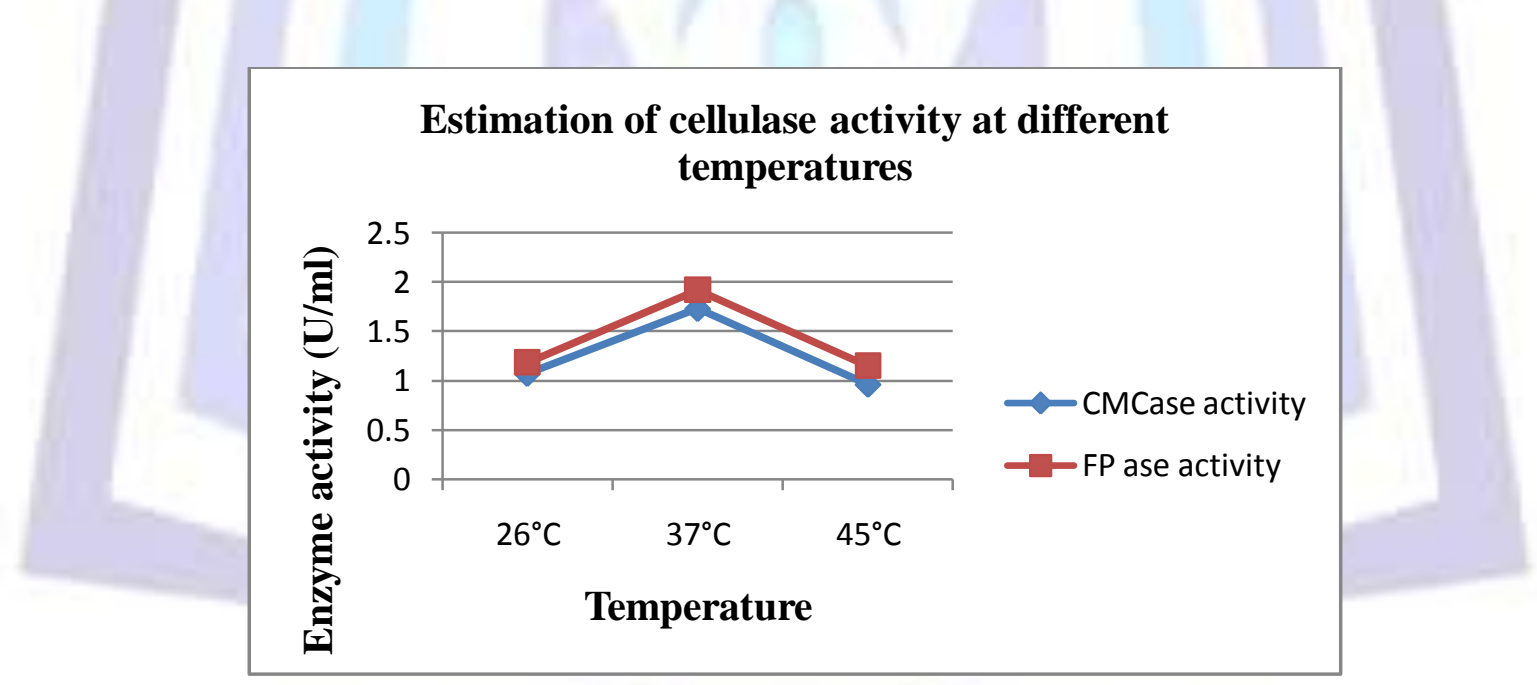

Fig2:Estimation of CMCase and FPase activity $(\mathrm{U} / \mathrm{ml})$ of Brevibacillus brevis strain St-2 at different temperatures

\subsection{Molecular Characterization and Phylogenetic Analysis}

The molecular characterization and phylogenetic analysis of the isolate showed $99 \%$ similarity score with Brevibacillus brevis having BLAST score ranging between 821 to 827 bits. The taxonomic position of the isolated strain was confirmed by sequencing full length of 16S rRNA gene sequence. An almost complete 16S rRNA gene sequence (1429 bp) for strain St-2 was used for constructing the phylogenetic Neighbor-Joining tree as shown in the Figure 3.

The evolutionary history was inferred using the Neighbor-Joining method [12]. The tree is drawn to scale, with branch lengths in the same units as those of the evolutionary distances used to infer the phylogenetic tree. The evolutionary distances were computed using the Maximum Composite Likelihood method [20] and are in the units of the number of base substitutions per site. The analysis involved 40 nucleotide sequences. Codon positions included were $1 \mathrm{st}+2 \mathrm{nd}+3 \mathrm{rd}+$ Noncoding. All positions containing gaps and missing data were eliminated. Evolutionary analyses were conducted in MEGA5 [13].

The 16S rRNA sequence of strain St-2 determined in this study (1,429 nucleotides) has been deposited in the GenBank database with the Accession No. KF306223. 


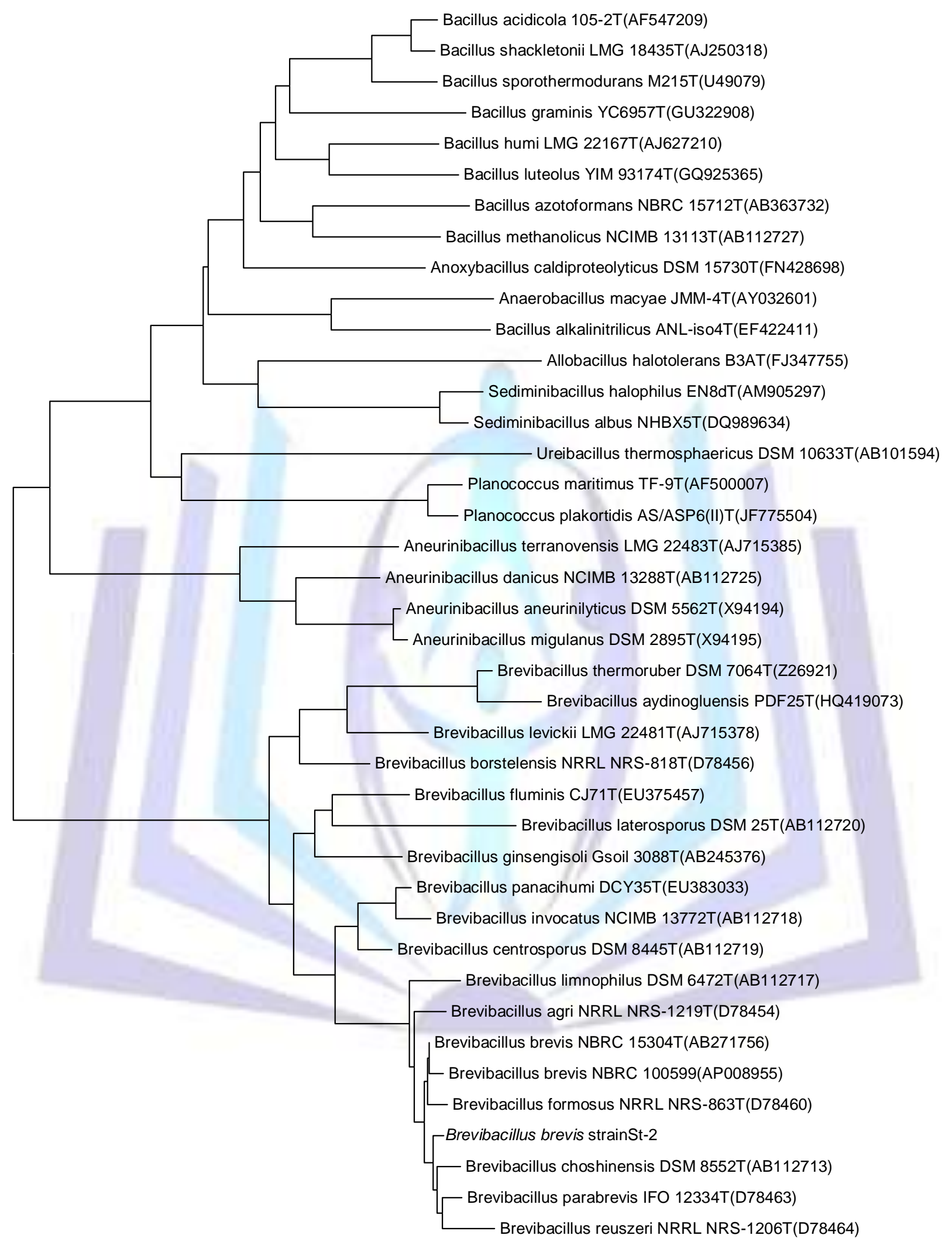

Fig 3: Evolutionary Relationships of Taxa 


\section{DISCUSSIONS}

For commercial purposes, the microbial cellulases are more cost effective than the plant cellulases as they can be easily improved by genetic manipulation and cultivated on large-scale. Majority of the studies on cellulases production have been focused on fungi that include Bulgaria, Chaetomium, and Helotium (Ascomycetes); Coriolus, Phanerochaete, Poria, Schizophyllum and Serpula (Basidiomycetes); and Aspergillus, Cladosporium, Fusarium, Geotrichum, Myrothecium, Paecilomyces, Penicillium, and Trichoderma (Deuteromycetes) as reported by Carlile and Watkinson [21]; and the bacterial genera explored by Lynd et al. [22] include Clostridium, Ruminococcus, and Caldicellulosiruptor (anaerobic gram positive); Butyrivibrio, Acetivibrioand Fibrobacter (anaerobic gram-negative); Cellulomonas, Bacillus and Thermobifida (aerobic gram-positive bacteria); and Cytophaga, and Sporocytophaga (aerobic gliding bacteria). The information available in the scientific literature about Brevibacillus brevis as a cellulases producer is scarce. Therefore, finding Brevibacillus brevis St-2 bearing potentialities for cellulose degradation in a wide variety of environmental conditions is one of the most outstanding results of this research. Culture conditions play a prominent role on formation of endoglucanase from bacteria [23] and therefore, optimization of fermentation media ingredients and environmental factors is definitely an effective strategy for enhanced cellulase enzyme production [24].

\section{ACKNOWLEDGEMENTS}

The authors gratefully acknowledge Department of Science and Technology, Ministry of Science and Technology, Govt. of India for financial support under WOS-A scheme and Dr. (Sister) Doris D'Souza, A.C., Principal, Patna Women's College for providing necessary infrastructural facilities.

\section{REFERENCES}

[1] Ryu, D. and Mandels, M. 1980. Cellulases: biosynthesis and applications. Enzyme Microbiol. Technol. 2: 90103.

[2] Lynd, L. R., Elander, R. T. and Wyman, C. E. 1996. Likely features and costs of mature biomass ethanol technology. Appl. Biochem. Biotech. 58: 741-761.

[3] Miranda, M., Kam, T. L. and Wensheng, Q. 2009. The prospects of cellulases-producing bacteria for the bioconversion of lignocellulosic biomass. Int. J. Biol. Sci. 5: 500-516.

[4] Kasana, R. C., Salwan, R., Dhar, H., Dutt, S. and Gulati, A. 2008. A rapid and easy method for the detection of microbial cellulasess on agar plates using Gram's iodine. Curr. Microbiol. 57: 503-507.

[5] Dubey, R. C. and Maheshwari, D. K. 2002. Practical Microbiology. S. Chand \& Company Ltd., New Delhi.

[6] Immanuel, G., Dhanusha, R., Prema, P. and Palavesam, A. 2006. Effect of different growth parameters on endoglucanase enzyme activity by bacteria isolated from coir retting effluents of estuarine environment. Int. J. Environ. Sci. Technol. 3: 25-34.

[7] Pridham, T. G. and Gottlieb, D. 1948. The utilization of carbon compounds by some actinomycetes as an aid for species determination. J. Bacteriol. 56: 107-114.

[8] Tresner, H. D., Hayes, J. A. and Backus, E. J. 1968. Differential tolerance of streptomycetes to sodium chloride as a taxonomic aid. Appl. Microbiol. 16: 1134-1136.

[9] Ghosh, T. K. 1987. Measurement of cellulase activities. Pure \& Appl. Chem. 59: 257- 268

[10] Brosius, J., Palmer, M. L., Kennedy, P. J. and Noller, H. F. 1978. Complete nucleotide sequence of a 16S ribosomal RNA gene from Escherichia coli. In Proceedings of National Academy of Science (USA) 75: 48014805.

[11] Altschul, S. F., Jenkins, A., Kristiansen, B. E. and FrØholm, C. O. 1990. Basic local alignment search tool. J. Mol. Bio.215: 403-410.

[12] Saitou, N. and Nei, M. 1987. The neighbour joining method; a new method for reconstructing phylogenetic trees. Mol. Biol. Evol. 4: 406-425.

[13] Tamura, K., Peterson, D., Peterson, N., Stecher, G., Nei, M. and Kumar, S. 2011. MEGA5: Molecular evolutionary genetics analysis using maximum likelihood, evolutionary distance and maximum parsimony methods. Mol. Biol. Evol.28: 2731-2739.

[14] Palmer, J. K. 1975. Liquid chromatography for monitoring the conversion of cellulosic wastes to sugars. Appl. Polym. Symp. 28: 237-245.

[15] Gokhan Coral, G., Burhan, A. N., Naldi, M. and Hatice, G. V. 2002. Some Properties of Crude CarboxymethylCellulase of Aspergillusniger Z10 wild-type strain. Turkish. J. Biol. 26: 209-213.

[16] Akiba, S., Kimura, Y., Yamamoto, K. and Kumagap, H. 1995. Purification and characterization of a proteaseresistant cellulase from Aspergillusniger. J. Fermen. Bioengin. 79:125-132.

[17] Garcia-Martinez, D. V., Shinmyo, A., Madia, A. and Deman, A. L. 1980. Studies on cellulase production by Clostridium thermocellum.Europ. J. Appl. Microbiol. Biotechnol. 9:189-197.

[18] Prasetsan, P. and Doelle, H. W. 1987. Nutrient optimization for cellulase biosynthesis by a newly isolated Cellulomonas sp. Mircen. J. 3: 33-44.

[19] Mandels, M., Hontz, L. and Nystron, J. 1974. Enzymatic hydrolysis of waste cellulose. Biotech. Bioengin. 16: 147-1493.

[20] Tamura, K., Nei, M. and Kumar, S. 2004. Prospects for inferring very large phylogenies by using the neighborjoining method. In Proceedings of National Academy of Science(USA) 101: 11030-11035.

[21] Carlile, M. J. and Watkinson,S. C. 1997. The fungi Academic Press, New York, 269- 275.

[22] Lynd, L. R., Paul, J. W., Van Zyl, W. H. and Pretorius, I. S. 2002. Microbial Cellulose Utilization: Fundamentals and Biotechnology. Microbiol. Mole. Biol. Rev. 66: 506-577. 


\section{ISSN 2348-6201}

[23] Levin, L., Forchiassin, F. 1995. Effect of carbon and nitrogen sources on the cellulolytic activity of Trametestrogii. Rev. Argent. Microbiol. 27: 11-20.

[24] Van Zyl, W. H. 1985. A Study of the cellulases produced by three mesophilicactinomycetes grown on bagasse as substrate. Biotechnol. Bioeng. 27: 1367-1373.

\section{Author' biography}

Dr Pinky Prasad completed her PhD in Botany from Patna University of Bihar in India. She is pursuing a research work as a Woman Scientist in the Department of Science \& Technology, Govt. of India. She has published more than 10 papers in reputed International and National journals. Her fields of research are: Microbiology and Environmental Biology. 